\title{
Messenger RNA levels of plasma proteins following fasting
}

\author{
BY FELICE A. DE JONG \\ Biotechnology Australia Pty Ltd, Roseville, NSW 2069, Australia \\ AND GEOFFREY J.HOWLETT AND GERHARD SCHREIBER \\ The Russell Grimwade School of Biochemistry, University of Melbourne, Parkville, \\ Victoria 3052, Australia
}

(Received 9 March 1987 - Accepted 31 July 1987)

\begin{abstract}
1. The effect of fasting on hepatic mRNA levels of seven plasma proteins was examined in the rat.
2. The levels of mRNA were measured directly in cytoplasmic extracts by hybridization to specific ${ }^{32} \mathrm{P}$-labelled cDNA probes.

3. Following a $48 \mathrm{~h}$ period of fasting, the mRNA levels of apolipoprotein $\mathrm{E}$, apolipoprotein A-IV, albumin, transferrin, and transthyretin decreased by $1530 \%$, while apolipoprotein A-II decreased by $78 \%$ compared with non-fasted control rats. The mRNA for apolipoprotein A-I increased by $33 \%$.

4. These findings suggest that mRNA levels in the liver following fasting are regulated independently and variations in these levels may be due to differences in transcription rates or mRNA stability.
\end{abstract}

Investigations into the effects of starvation on the content of ribosomes (Webb et al. 1966; Henshaw et al. 1971; Wilson et al. 1967), DNA (Ramsey \& Stcele, 1976), RNA (Henderson, 1970) and protein (Enwonwu \& Munro, 1970; Ramsey \& Steele 1976) in rat liver have been reported. It has been shown that RNA polymerase activity decreases markedly during starvation (Henderson, 1970), and refeeding increases RNA synthesis and RNA polymerase activity following fasting (Kosterlitz, 1947; Laird et al. 1955; Kirsch et al. 1968; Rothschild et al. 1968; Henderson, 1970; Vesley \& Cihak, 1970). Decreases in protein synthesis in the liver following fasting parallel decreases in ribosome content, decreases in polyribosome activity and a disaggregation of polyribosomes (Hirsche \& Hiatt, 1966; Reid et al. 1970; Henshaw et al. 1971; McNurlan et al. 1972; Yap \& Hafkenscheid, 1978). Studies have demonstrated that mRNA is necessary for the structural integrity of the polyribosome (Warner et al. 1962; Noll et al. 1963; Staehelin et al. 1963; Trakatellis et al. 1964). The hepatic mRNA levels for albumin have been studied in animal models following fasting by a number of investigators (Pain et al. 1978; Yap et al. 1981; Goldman et al. 1985, Howard et al. 1986).

In the present paper, the relative mRNA levels for albumin, as well as transferrin, transthyretin, apolipoprotein (Apo) A-I, Apo A-II, Apo A-IV and Apo E were measured by hybridization techniques using specific cDNA probes in rats fasted for $2 \mathrm{~d}$.

\section{METHODS \\ Animals and materials}

Male Buffalo rats from an inbred strain, weighing 230-280 g, were fed on a standard laboratory rat chow (GR2 + Ration; Clark King and Co., Allied Mills Industries Pty Ltd, North Melbourne) containing (g/ kg) 200 protein, 20 crude fat and 30 crude fibre, and were fed ad lib. or fasted for $48 \mathrm{~h}$. Rats were housed in a constant-temperature room at $22^{\circ}$ with a $12 \mathrm{~h}$ light period from 08.00 to 20.00 hours and weighed before and after the $48 \mathrm{~h}$ experimental period. All experimental procedures were performed between 09.00 and 12.00 hours. 
Nitrocellulose filters were purchased from Schleicher and Schull, Dassel, West Germany, ribonuclease A from Boehringer, Mannheim, West Germany and $\left[\alpha^{-32} \mathrm{P}\right] \mathrm{dATP}$ and $\left[\alpha^{-32} \mathrm{P}\right] \mathrm{dCTP}$ (specific radioactivity $>3000 \mathrm{Ci} / \mathrm{mmol}$ ) from Amersham International plc, Amersham, Bucks. All reagents were of analytical grade.

\section{Preparation of cytoplasmic extracts and total $R N A$ from livers}

Livers were removed from rats under diethyl ether anaesthesia and homogenized in a cold solution of 10 mM-Tris hydrochloride ( $\mathrm{pH} 7 \cdot 0), 1$ mM-EDTA, Nonidet P-40 $(5 \mathrm{~g} / 1 ; 10 \mathrm{ml} / \mathrm{g}$ liver) with a $30 \mathrm{ml}$ Potter Elvehjem homogenizer. The homogenate was centrifuged at $4^{\circ}$ $(15000 \mathrm{~g}, 5 \mathrm{~min})$ and portions of the supernatant fractions taken. To $1 \mathrm{ml}$ supernatant fraction, $600 \mu \mathrm{l}$ of $20 \times$ standard saline citrate $(3 \mathrm{M}-\mathrm{NaCl}, 0 \cdot 3 \mathrm{M}$-trisodium citrate) and $400 \mu \mathrm{l}$ $37 \%(\mathrm{w} / \mathrm{v})$ formaldehyde were added. The mixture was incubated at $60^{\circ}$ for $15 \mathrm{~min}$ and centrifuged at $4^{\circ}(15000 \mathrm{~g}, 15 \mathrm{~min})$. Control samples were prepared by incubation of $500 \mu \mathrm{l}$ of the supernatant fraction from the tissue homogenate with ribonuclease $\mathrm{A}(E C$ 3 1.27.5; $0.04 \mathrm{mg} / \mathrm{ml}$ final concentration) and $400 \mu \mathrm{l}$ cold $10 \mathrm{~mm}$-Tris hydrochloride, $\mathrm{pH} 7.0,1 \mathrm{~mm}-$ EDTA, Nonidet $(5 \mathrm{~g} / \mathrm{l})$ for $1 \mathrm{~h}$ at $37^{\circ}$. After centrifugation at $4^{\circ}(15000 \mathrm{~g}, 15 \mathrm{~min})$ standard saline citrate and formaldehyde were added and processed as before. All processed extracts were stored at $-70^{\circ}$. The tissue extracts were diluted $1: 20(\mathrm{v} / \mathrm{v} ; 1: 10$ for ribonuclease-treated controls) with $1.2 \mathrm{M}$-sodium chloride, $0 \cdot 112 \mathrm{M}$-trisodium citrate before spotting on to nitrocellulose filters using a Biorad 'Biodot' apparatus. Total RNA was prepared by homogenizing liver with a Potter Elvehjem homogenizer in $5 \mathrm{M}$-guanidinium thiocyanate containing $50 \mathrm{~mm}$-sodium citrate $(\mathrm{pH} 7 \cdot 0), 0 \cdot 1 \mathrm{M}-\beta$-mercaptoethanol and $n$ laurylsarcosine $(1 \mathrm{~g} / 1 ; 10 \mathrm{ml} / \mathrm{g}$ liver $)$. The homogenate was layered over a cushion of $1 \mathrm{ml}$ $5.65 \mathrm{M}$-CsCl. The homogenate was overlayered in turn by $5 \mathrm{ml}$ sterile $\mathrm{H}_{2} \mathrm{O}$. The pellet obtained after centrifugation for $18 \mathrm{~h}$ at $185000 \mathrm{~g}$ was resuspended in $2 \mathrm{ml} 10 \mathrm{~mm}$-Tris hydrochloride ( $\mathrm{pH} \mathrm{7.6)} \mathrm{containing} 10$ mM-EDTA. Protein was extracted by adding $4 \mathrm{ml}$ of a mixture of chloroform-butanol $(4: 1 ; \mathrm{v} / \mathrm{v})$ followed by rigorous shaking. After separation of the phases by a short centrifugation, the aqueous phase was removed and the organic

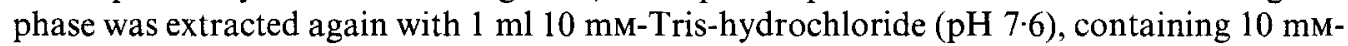
EDTA. The aqueous phases were combined and RNA was precipitated by adding 2 vols

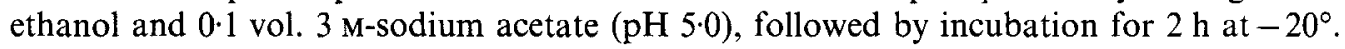
The precipitated RNA was resuspended in $0.03 \mathrm{ml}$ sterile $\mathrm{H}_{2} \mathrm{O}$. The total liver RNA was subjected to 'Northern' analysis (Thomas, 1980).

\section{Synthesis of radioactively-labelled probes}

Specific cDNA clones for plasma proteins in plasmid pBR325 or bacteriophage $\lambda \mathrm{gt} 11$ Amp3 were used to obtain probes for measuring mRNA levels. Characteristics of the clones for albumin (Schreiber et al. 1986), transferrin (Aldred et al. 1984), transthyretin (Dickson et al. 1985), Apo E (de Jong et al. 1984), and Apo A-I, Apo A-II and Apo A-IV (Guo-Fen et al. 1987) have been described elsewhere. Inserts from clones were isolated and nicktranslated (Maniatis et al. 1982) to produce ${ }^{32} \mathrm{P}$-labelled probes. These probes were then allowed to hybridize to their respective $m$ RNA bound to nitrocellulose filters (Thomas, 1980). Following autoradiography on Kodak XRP film at $-70^{\circ}$ with an intensifying screen, the areas on the nitrocellulose filters with hybridized cDNA were cut out and the bound radioactivity was quantified by liquid-scintillation spectrophotometry in toluene containing 5 g 2,5-diphenoloxazolel. Relative mRNA levels for plasma proteins were calculated as radioactivity bound to mRNA on the filters (minus background) as a percentage of the value for normal rats, corrected for decreases in body-weight and liver weight during fasting. 


\section{Statistical evaluation}

Five animals were used for each time-point. Means with their standard errors were calculated. Statistical evaluation of body-weight and liver weight was performed using Student's $t$ test, $P<0.05$ being considered as statistically significant.

\section{RESULTS}

Cytoplasmic extracts were prepared from rat liver and mRNA levels were measured by hybridization to specific $\alpha{ }^{32} \mathrm{P}$-labelled cDNA for albumin, transferrin, transthyretin, Apo A-I, Apo E, Apo A-II and Apo A-IV. As an example, Plate 1 shows hybridization of cDNA obtained for rat serum albumin (RSA), Apo A-I and Apo E to RNA in extracts from livers of control and $48 \mathrm{~h}$ fasted rats. As seen in lane A of Plate 1, hybridization signals obtained from cytoplasmic extracts increased in intensity when increased amounts of extract were added. In the quantitative analysis of radioactivity bound to excised dots by liquidscintillation spectrometry, a linear relation existed between bound radioactivity and amount of extract in the dots.

Fasting for $48 \mathrm{~h}$ resulted in a decrease of body-weight compared with non-fasted controls $(251$ (SE 10, $n$ 5) v. 221 (SE 9, $n$ 5) g; $P<0.05$ ), and a decrease in liver weight compared with non-fasted controls $(10.3$ (SE $0.5, n 5)$ v. 6.3 (SE $0.2, n 5) \mathrm{g} ; P<0.001$ ). The average liver weight of control animals was $3.96 \%$ of body-weight, whereas after $48 \mathrm{~h}$ fasting the liver weight was only $2.85 \%$ of total body-weight. Table 1 shows quantitative mRNA levels as a percentage of control values for the seven proteins studied before and after correction for the disproportionate loss of liver weight. As the results obtained for each time-point were determined for a fixed amount of liver, it is necessary to account for the greater decrease in liver weight relative to body-weight in order to compare the synthesis of different mRNAs by the whole liver. To eliminate the effect of differences in rat size the change in liver weight as a percentage of initial body-weight was used to calculate the results presented in Table 1 (corrected mRNA levels):

$$
\text { mRNA( } \% \text { control }) \times \frac{\% \text { experimental liver weight }}{\% \text { control liver weight }} \text {. }
$$

After correcting for liver weight loss, the amount of mRNA for albumin, transferrin, Apo A-IV and Apo E in the whole liver were seen to decrease 15-30\% following the $48 \mathrm{~h}$ fasting period. Apo A-I mRNA levels increased $33 \%$ compared with control levels. The largest change was observed for Apo A-II, where mRNA levels fell to $22 \%$ of control values.

Total RNA was prepared from livers of control and $48 \mathrm{~h}$ fasted rats and subjected to 'Northern' analysis. As an example, Plate 2 shows cDNA for Apo A-I, Apo A-II, Apo AIV, Apo E and albumin hybridizing to specific RNA species. The intensities of bands obtained from hybridization also shows a decreased level of mRNA for Apo A-II, and an increase in mRNA for Apo A-I following the $48 \mathrm{~h}$ fasting period.

\section{DISCUSSION}

The results obtained by the technique of cytoplasmic dot hybridization used to measure changes in specific mRNA levels of albumin, transferrin, transthyretin, Apo A-I, Apo AII, Apo A-IV and Apo E in rat liver during fasting are consistent with the assumption that these levels are regulated independently during fasting.

Nutritional status has a profound effect on the activity of hepatic enzymes and the rate 
Table 1. Liver mRNA levels* in rats after 48 h fasting as a percentage of control values (Mean values with their standard errors for five animals)

\begin{tabular}{|c|c|c|c|c|}
\hline \multirow[b]{2}{*}{ Protein } & \multicolumn{2}{|c|}{$\begin{array}{l}\text { Uncorrected (counts/min per } \\
\text { g liver) mRNA level } \\
(\% \text { control value })\end{array}$} & \multicolumn{2}{|c|}{$\begin{array}{l}\text { Corrected (counts/min per } \\
\text { whole liver) mRNA level } \\
(\% \text { control value })\end{array}$} \\
\hline & Mean & $\mathrm{SE}$ & Mean & $\mathrm{SE}$ \\
\hline Albumin & 136 & 11 & 86 & 7 \\
\hline Transferrin & 105 & 13 & 67 & 8 \\
\hline Transthyretin & 107 & 10 & 68 & 6 \\
\hline Apo A-I & 209 & 17 & 133 & 11 \\
\hline Apo A-II & 35 & 4 & 22 & 3 \\
\hline Apo A-IV & 114 & 11 & 72 & 7 \\
\hline Apo E & 135 & 12 & 86 & 8 \\
\hline
\end{tabular}

Apo, apolipoprotein.

* mRNA levels determined as described on p. 82 .

of protein synthesis. In studies where fasted mice (pretreated with actinomycin D) were tube fed on tryptophan, elevated cytoplasmic mRNA levels, increases in polysomal aggregates, and an increase in protein synthesis were observed (Murty \& Sidransky, 1972). Later studies revealed that tryptophan may act to stimulate the transport of mRNA into the cytoplasm of the liver (Murty et al. 1976). These studies indicate that amino acids, in particular tryptophan, play a part in the regulation of protein synthesis. However, other experiments show that amino acid concentrations in liver cytosol are unchanged following fasting (Yap \& Hafkenscheid, 1981). These and other studies suggest that liver protein synthesis may be regulated by transcriptional or post-transcriptional mechanisms during starvation and not amino acid availability (Princen et al. 1983).

Nuclear RNA containing the primary transcript exists in association with proteins in the form of ribonucleoprotein particles (mRNP). Transport of the mRNP complex into the cytoplasm and incorporation into polysomes has been postulated (Spirin, 1966; Henshaw, 1968). Increases in free ribosomes following starvation have been reported in cultured mouse and human cells (Hogan \& Korner, 1968; Lee et al. 1971 ; Vaughan et al. 1971; van Venrooij et al. 1972). The mRNA released by polysomes during starvation is in the untranslated ribonucleoprotein form (mRNP) which is stored in the cytoplasm and is readily available for uptake into the polysomes (Lee et al. 1971; Sonenstein \& Brawerman, 1977; Yap et al. 1978). Addition of nutrients to starved cells results in rapid polysome formation (Lee et al. 1971; Sonenstein \& Brawerman, 1977).

When the effect of starvation on translatable mRNA for liver-specific proteins was tested it was found that overall template activity of mRNA/ $\mu$ g RNA in both polysomal and total RNA was slightly decreased (Howard et al. 1986). In the same study, translatable albumin mRNA (from both RNA populations) was reported to decrease $20-40 \%$. These results agree with decreases in albumin mRNA observed by Pain et al. (1978) following protein depletion. Other studies show no changes in hepatic albumin mRNA levels following fasting. Goldman et al. (1985) reported that the synthesis of hepatic albumin mRNA was little affected in ducklings starved for $2 \mathrm{~d}$. Results obtained by Yap et al. (1978) demonstrate that although albumin $\mathrm{mRNA}$ levels decrease in membrane-bound ribosomes they accumulate in postpolysomal ribonucleoprotein fractions following a short-term fast (24-30 h). In studies reported by Wilson \& Hoagland, (1967) and Wilson et al. (1967) a decrease in polysomes and total RNA synthesis was observed in the livers of rats starved 
for $5 \mathrm{~d}$ and treated with actinomycin $\mathrm{D}$. In the same studies an increase of albumin relative to other proteins was demonstrated suggesting that albumin mRNA was more stable than other mRNA in liver.

In the present study we observed that the levels of mRNA for albumin in the whole liver decreased by only $10-20 \%$ in rats fasted for $48 \mathrm{~h}$. These observations may reflect the increased levels of postpolysomal albumin mRNA observed by others (Yap et al. 1978) as well as the stability of albumin mRNA (Wilson \& Hoagland, 1967; Wilson et al. 1967). It should be noted that our results, as well as the results obtained by Yap \& Hafkenscheid (1981) and Goldman et al. (1985), are based on molecular hybridization techniques. These techniques rely on the assumption that all the mRNA transcripts can be detected and are fully functional.

During fasting the concentration of plasma transthyretin (prealbumin) in the rat has been reported to decrease to about $50 \%$ of normal levels (Felding \& Fex, 1983). The results presented here suggest that this may be due to decreased hepatic mRNA levels for this protein. Similar changes in plasma transthyretin and hepatic mRNA levels (Dickson et al. 1985) have been reported in response to acute inflammation.

In our studies Apo A-II mRNA levels were shown to change the most, decreasing to $22 \%$ of normal levels. Decreases in lipolytic activity during fasting have been shown to reduce liver lipid synthesis (Burton et al. 1969). Hepatic triglyceride lipase activity in the rat has been reported to decrease following a period of fasting for $24 \mathrm{~h}$ (Elkeles \& Hambley, 1977). It has been demonstrated that Apo A-II may play a role in vivo in the activation of hepatic lipase activity and high-density lipoprotein metabolism (Jahn et al. 1983). This decrease in hepatic lipase activity following fasting is consistent with diminished mRNA levels of activator, Apo A-II.

In the present study, the independent alterations of specific mRNA levels described following fasting may be caused by: (1) changes in rates of transcription, (2) differences in the rates in delivery of mRNA from the nucleus to the cytoplasm, or (3) differences in mRNA stability.

The authors would like to thank A. Aldred, P. Dickson, T. Guo-Fen and M. Nagashima for providing cDNA for transferrin, transthyretin, Apo A-I and albumin, and Apo A-II respectively.

\section{REFERENCES}

Aldred, A. R., Howlett, G. J. \& Schreiber, G. (1984). Biochemical Biophysical Research Communications 122, $960-965$.

Burton, D. N., Collins, J. M., Kernan, A. L. \& Porter, J. W. (1969). Journal of Biological Chemistry 244, $4510-4516$.

de Jong, F. A., Howlett, G., Aldred, A. R., Fidge, N. \& Schreiber, G. (1984). Biochemical Biophysical Research Communications 119, 657-662.

Dickson, P. W., Howlett, G. J. \& Schreiber, G. (1985). Journal of Biological Chemistry 260, 8214-8219.

Elkeles, R. S. \& Hambley, J. (1977). Diabetes 26, 58-60.

Enwonwu, C. O. \& Munro, H. N. (1970). Archives of Biochemistry and Biophysics 138, 532-539.

Felding, P. \& Fex, G. (1983). Acta Physiologica Scandinavica 117, 377-383.

Goldman, J. J., Back, D. W. \& Goodridge, A. G. (1985). Journal of Biological Chemistry 260, 44044408.

Guo-Fen, T., de Jong, F., Apostolopoulos, J, Nagashima, M., Fidge, N., Schreiber, G. \& Howlett, G. (1987). Inflammation 11, 241-251.

Henderson, A. R. (1970). Biochemical Journal 120, 205-214.

Henshaw, E. C. (1968). Journal of Molecular Biology 36, 401-411.

Henshaw, E. C., Hirsch, C. A., Morton, B. E. \& Hiatt, H. H. (1971). Journal of Biological Chemistry 246, 436-446.

Hirsch, C. A. \& Hiatt, H. H. (1966). Journal of Biological Chemistry 241, 5936-5940.

Hogan, B. L. M. \& Korner, A. (1968). Biochimica et Biophysica Acta 169, 129-138. 
Howard, G., Chitpatima, S. T., Feldhoff, R. C. \& Geoghegan, T. E. (1986). Proceedings of the Society for Experimental Biology and Medicine 181, 312-317.

Jahn, C. E., Osborne, J. C. Jr, Schaefer, E. J. \& Brewer H. B. Jr (1983). European Journal of Biochemistry 131, 25-29.

Kirsch, R., Frith, L., Black, E. \& Hoffenberg, R. (1968). Nature 217, 578-579.

Kosterlitz, H. W. (1947). Journal of Physiology 106, 194-210.

Laird, A. K., Barton, A. D. \& Nygaard, O. (1955). Experimental Cell Research 9, 523-540.

Lee, S. Y. Krsmanovic, V. \& Brawerman, G. (1971). Biochemistry 10, 895-900.

McNurlan, M. A., Tomkins, A. M. \& Garlick, P. J. (1972). Biochemistry Journal 178, 373-379.

Maniatis, T., Fritsch, E. F. \& Sambrook, J. (1982). In Molecular Cloning, pp. 109-112 [T. Maniatis, E. F. Fritsch and J. Sambrook, editors]. New York: Cold Spring Harbor Laboratory.

Murty, C. N. \& Sidransky, H. (1972). Biochimica et Biophysica Acta 262 328-335.

Murty, C. N., Verney, E. \& Sidransky, H. (1976). Laboratory Investigation 34, 77-85.

Noll, H., Staehelin, T. \& Wettstein, F. O. (1963). Nature 198, 632-638.

Pain, V. M., Clemens, M. J. \& Garlick, P. J. (1978). Biochemical Journal 172, 129-135.

Princen, J. M. G., Mol-Backx, G. P. B. M. \& Yap, S. H. (1983). Annals of Nutrition and Metabolism 27, $182-193$.

Ramsey, J. C. \& Steele, W. J. (1976). Biochimica et Biophysica Acta 447, 312-318.

Reid, I. M., Very, E. \& Sidransky, H. (1970). Journal of Nutrition 100, 1149-1156.

Rothschild, M. A., Oratz, M., Mongelli, J. \& Schreiber, S. S. (1968). Journal of Clinical Investigation 47, 2591-2599.

Schreiber, G., Aldred, A. R., Thomas, T., Birch, H. E., Dickson, P. W., Guo-Fen., Heinrich, P. C., Howlett, G. J., de Jong, F. A. \& Mitchell, A. (1986). Inflammation 10, 5966.

Sonenstein, G. E. \& Brawerman, G. (1977). European Journal of Biochemistry 73, 307-312.

Spirin, A. S. (1966). In Current Topics in Developmental Biology, vol. 1, p. 1 [A. Monroy and A. A. Moscana, editors]. New York: Academic Press.

Staehelin, T., Wettstein, F. O. \& Noll, H. (1963). Science 140, 80-83.

Thomas, P. S. (1980). Proceedings of the National Academy of Science, U.S.A. 77, 5201-5205.

Trakatellis, A. C., Axelrod, A. E. \& Montjar, M. (1964). Journal of Biological Chemistry 239, 4237-4244.

van Venrooij, W. J. W., Henshaw, E. C. \& Hirsch, C. A. (1972). Biochimica et Biophysica Acta 259, $127-137$.

Vaughan, M. H., Pawlowski, P. J. \& Forchhammer, T. (1971). Proceedings of the National Academy of Science, U.S.A. 68, 2057-2061

Vesley, J. \& Cihak, A. (1970). Biochimica et Biophysica Acta 204, 614-616.

Warner, J. R., Rich, A. \& Hall, C. E. (1962). Science 138, 1399-1403.

Webb, T. E., Blobel, G. \& Potter, V. R. (1966). Cancer Research 26, 253-257.

Wilson, S. H., Hill, H. Z. \& Hoagland, M. B. (1967); Biochemical Journal 103, 567-572.

Wilson, S. H. \& Hoagland, M. B. (1967). Biochemical Journal 103, 556-566.

Yap, S. H. \& Hafkenscheid, J. C. M. (1981). Annals of Nutrition and Metabolism 25, 158-164.

Yap, S. H., Strair, R. K. \& Shafritz, D. A. (1978). Journal of Biological Chemistry 253, 4944-4950.

\section{EXPLANATION OF PLATES}

Plate 1. Rat mRNA levels following fasting. Cytoplasmic mRNA extracts spotted on to nitrocellulose paper and hybridized to specific cDNA for rat serum albumin (RSA), apolipoprotein A-I (Apo A-I) and apolipoprotein E (Apo E). Autoradiography was at $-70^{\circ}$ using Kodak XRP film and an intensifying screen was used for $24 \mathrm{~h}$. Autoradiographs for RSA, Apo A-I and Apo E are from identical filters. Lane A shows hybridization to RNA obtained for cytoplasmic extracts from (columns $1-6$ respectively) $2500,1000,500,250,100$ and $50 \mu$ g liver pooled from five control rats. Lane B (columns 1 and 2,3 and 4,5 and 6,7 and 8,9 and 10, in duplicate) shows results obtained from $100 \mu \mathrm{g}$ liver from five individual control rats respectively. Lane $\mathrm{C}$, same as lane $\mathrm{B}$, except from five $48 \mathrm{~h}$-fasted rats. Columns 11 and 12 (lanes B and C) contain similar material as rows 9 and 10 next to them, but extracts were incubated with ribonuclease $A(E C 3.1 .27 .5)$ before formaldehyde treatment.

Plate 2. 'Northern' analysis of mRNA from $48 \mathrm{~h}$ fasted rat livers. Autoradiographs obtained from the analysis of apolipoprotein (Apo) A-I, Apo E, Apo A-IV, Apo A-Il and rat serum albumin (RSA). Total RNA ( $5 \mu \mathrm{g}$ : lanes Apo E and RSA) and total RNA (10 $\mu \mathrm{g}$ : lanes Apo A-I, Apo A-IV and Apo A-II), isolated from the liver of control rats $(N)$ and from 48 h-fasted rats $(F)$, was subjected to electrophoresis in a $1.2 \%$ agarose gel containing formaldehyde. Transfer of the RNA to nitrocellulose filters and hybridization with radiolabelled cDNA for Apo A-I, Apo E, Apo A-IV, Apo A-II and RSA was performed as described by Maniatis et al. (1982). Autoradiography was at $-70^{\circ}$ using Kodak XAR film and an intensifying screen for $3 \mathrm{~d}$. 

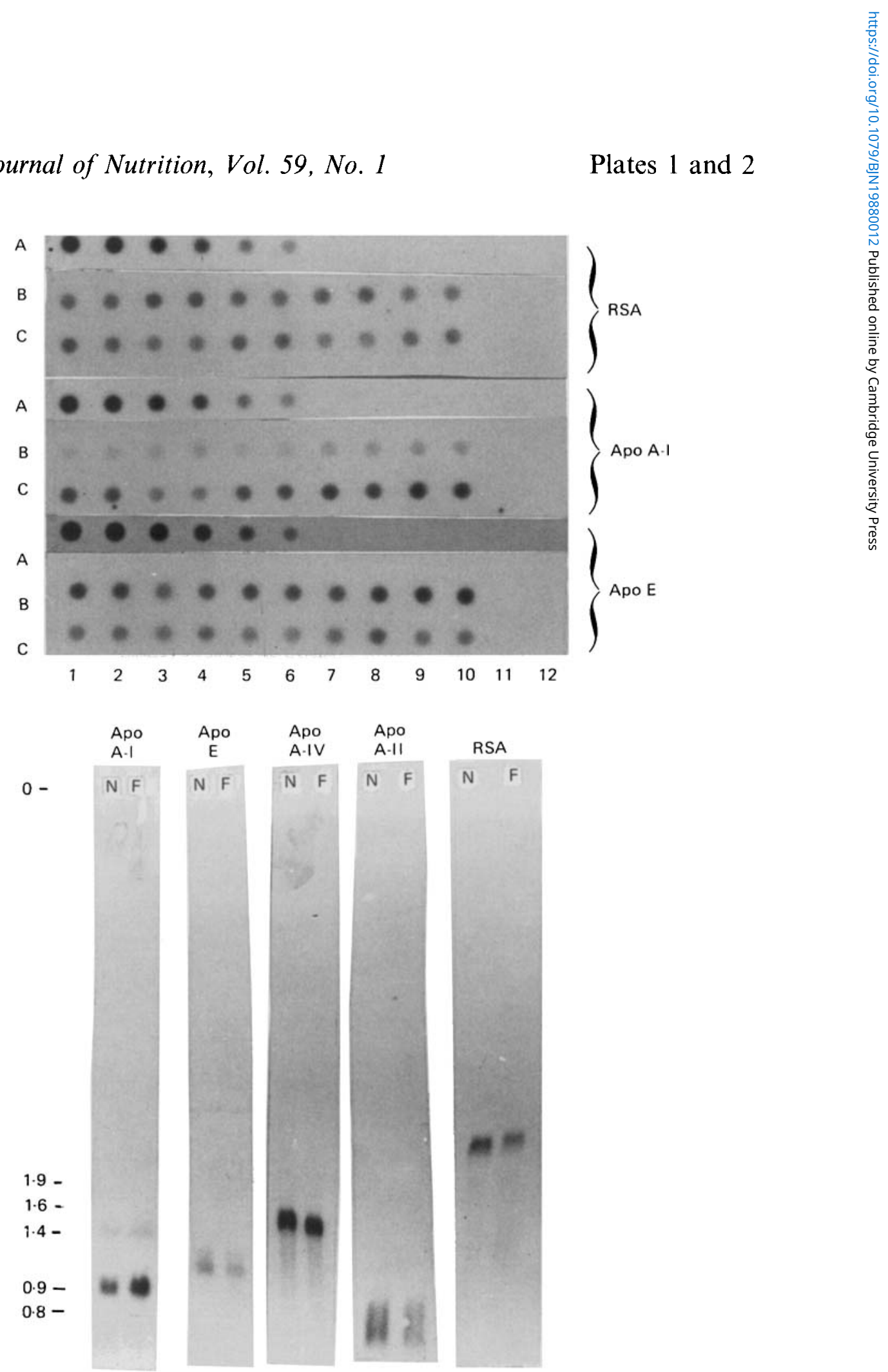